\title{
Population dynamics and biocontrol efficacy of the nematophagous fungus Hirsutella rhossiliensis as affected by stage of the soybean cyst nematode
}

\author{
Limei Zhang a,b, Ence Yang ${ }^{\mathrm{a}, \mathrm{c}}$, Meichun Xiang ${ }^{\mathrm{a}}$, Xingzhong Liu ${ }^{\mathrm{a}, *}$, Senyu Chen ${ }^{\mathrm{d}}$ \\ ${ }^{a}$ Key Laboratory of Systematic Mycology and Lichenology, Institute of Microbiology, Chinese Academy of Sciences, Datun Road, Chaoyang District, Beijing 100101, PR China \\ ${ }^{\mathrm{b}}$ State Key Laboratory of Urban and Regional Ecology, Research Centre for Eco-environmental Sciences, Chinese Academy of Sciences, Beijing 100085, China \\ ${ }^{\mathrm{C}}$ Graduate University of Chinese Academy of Sciences, Beijing 100049, PR China \\ ${ }^{\mathrm{d}}$ University of Minnesota, Southern Research and Outreach Center, Waseca, MN 56093, USA
}

\section{A R T I C L E I N F O}

\section{Article history}

Received 28 April 2008

Accepted 28 July 2008

Available online 7 August 2008

\section{Keywords:}

DNA yield

Real-time PCR

Heterodera glycines

Fungal parasitism

Nematode suppression

\begin{abstract}
A B S T R A C T
Monitoring the population dynamics of a biocontrol agent in soil is important for understanding, predicting and increasing its efficacy. In this study, the population dynamics and the efficacy of a promising biocontrol agent against nematode, the fungus Hirsutella rhossiliensis, were investigated in greenhouse experiments with quantitative real-time polymerase chain reaction (PCR) and bioassay. To explore the effects of the fungus on nematode inoculum, soil infested with eggs or second-stage juveniles (J2) of Heterodera glycines was used. The results showed that the quantity of $H$. rhossiliensis DNA based on real-time PCR decreased over time, regardless of eggs or J2 as inoculum. The quantity of $H$. rhossiliensis DNA [femtogram (fg)/g soil] was highest $\left(3.83 \pm 1.96 \times 10^{8} \mathrm{fg} / \mathrm{g}\right.$ soil) when the fungus was first added to soil and then decreased rapidly to $3.24 \pm 1.22 \times 10^{7} \mathrm{fg} / \mathrm{g}$ in egg-infested soil and $7.34 \pm 2.94 \times 10^{7} \mathrm{fg} / \mathrm{g}$ in J2infested soil 17 days after planting, and then declined gradually between 17 and 59 days after planting. The data based on the bioassay showed that the percentage of $\mathrm{J} 2$ parasitized by $H$. rhossiliensis decreased throughout the experiment in both egg- and J2-infested soils. H. rhossiliensis controlled H. glycines more effectively in J2-infested soil than in egg-infested soil. At the end of the experiments ( 59 days after planting), nematode suppression and plant growth promotion in J2-infested soil were $79 \%$ and $55 \%$, respectively, which were higher than the $34 \%$ and $2 \%$ in egg-infested soil. In soil that was not inoculated with the fungus, the number of $H$. glycines was 10 times higher in J2-infested soil than in egg-infested soil, indicating the greater nematode inoculum potential in soil infested with J2. DNA yield of $H$. rhossiliensis was statistically higher in J2-infested soil than in egg-infested soil in earlier period (prior to day 31) $(p<0.05)$, which is consistent with the hypothesis that the numbers of $\mathrm{J} 2$ present during and soon after fungal inoculation are critical for maintaining the population density and biocontrol efficiency of the fungus.
\end{abstract}

(c) 2008 Elsevier Inc. All rights reserved.

\section{Introduction}

The soybean cyst nematode (SCN), Heterodera glycines Ichinohe, is the most important pathogen of soybean (Wrather and Koenning, 2006). A number of widely used and effective chemical nematicides for controlling it have been banned in recent years due to environmental concerns (Rosskopf et al., 2005). This has fuelled increased interest in finding alternative methods for nematode control, one of which is biocontrol by natural enemies. One such natural enemy is the nematophagous fungus, Hirsutella rhossiliensis Minter and Brady, which occurs naturally in agricultural fields, and parasitizes vermiform stages of many species of soil-borne, plantparasitic nematodes (Ciancio et al., 1986; Jaffee and Muldoon, 1989; Jaffee et al., 1991; Hay, 1995; Velvis and Kamp, 1995; Liu

\footnotetext{
* Corresponding author. Fax: +86 1064807505.

E-mail address: liuxz@im.ac.cn (X. Liu).
}

and Chen, 2000). Because natural and artificial infestations cause high levels of nematode mortality in the field and in the laboratory, $H$. rhossiliensis is an attractive candidate as a potential biocontrol agent (Jaffee and Muldoon, 1989; Liu and Chen, 2001; Chen and Liu, 2005).

Hirsutella rhossiliensis, an endoparasitic fungus of nematodes, initiates infection by producing adhesive conidia that adhere to the cuticles of passing nematodes. Only the conidia that are attached to the phialides are infectious (McInnis and Jaffee, 1989), and one conidium is generally sufficient to infect a nematode. Once the fungus penetrates the nematode, it proliferates in the nematode body and produces new conidia within a few days (Lackey et al., 1992); these conidia then initiate a new round of infection. Although $H$. rhossiliensis significantly suppressed plant-parasitic nematodes in greenhouse and laboratory assays (Velvis and Kamp, 1996; Amin, 2000; Liu and Chen, 2001; Chen and Liu, 2005), the fungus did not reduce population densities of cyst and root-knot 
nematodes in some field trials (Tedford et al., 1993; Jaffee et al. 1996; Chen et al., unpublished data). Because the fungus provided inconsistent nematode suppression in different studies, we suspect that a better understanding of its ecology after being introduced into soil is critical for its successful use as an inundative commercial biocontrol agent. Understanding how the fungus does or does not suppress nematode numbers requires detailed knowledge of the population dynamics of both the fungus and its host. However, due to the limitations in methods for quantitatively monitoring the fungus in soil, most studies have inferred changes in $H$. rhossiliensis numbers by measuring changes in numbers of nematodes parasitized by the fungus, changes in numbers of resident nematodes or changes in plant growth. As a result, we lack direct measures of $H$. rhossiliensis population dynamics in soil.

When inoculum of a biocontrol agent is added to soil, many factors determine whether the agent will establish and control pest nematodes. Generally, soil is considered resistant to the introduction of new microorganisms (Cook and Baker, 1983; Stirling, 1991; Pereira et al., 1993; Jaffee, 1999). Soil organisms, soil abiotic factors (including $\mathrm{pH}$, soil moisture, porosity) and formulation of the agent affected the biocontrol potential of $H$. rhossiliensis (Tedford et al., 1992; Jaffee, 1999; Jaffee and Zasoski, 2001). In addition, as an endoparasitic fungus, $H$. rhossiliensis is considered obligately dependent on nematodes for nutrition in nature, and its parasitism on nematodes was positively correlated with host density (Jaffee et al., 1993; Jaffee and Muldoon, 1995). Lackey and co-workers (1994) reported that the fungus was more effective in soil infested with $\mathrm{J} 2$ than in soil infested with egg masses or cysts, but substantial variability occurred among trials. In previous studies, $H$. rhossiliensis isolate OWVT-1, obtained from a field continuously planted with soybean for more than 27 years, reduced egg and secondstage juvenile (J2) densities of SCN by more than $90 \%$ in the greenhouse (Liu and Chen, 2001; Chen and Liu, 2005). However, in the field, the fungus showed inconsistent suppression of SCN (Chen et al., unpublished data). In our preliminary experiment, the fungus also failed to suppress SCN in soil infested with eggs.

The objectives of the present study were to monitor the fate of $H$. rhossiliensis inoculum after it was added to soil and then to explore the possible effect of the predominant stage of SCN in soil on the efficacy of $H$. rhossiliensis. We used real-time polymerase chain reaction (PCR) to quantify $H$. rhossiliensis DNA in soil (Zhang et al., 2006) and a bioassay to quantify $H$. rhossiliensis parasitism of nematodes.

\section{Materials and methods}

\subsection{Fungal and nematode inoculum}

Hirsutella rhossiliensis, isolate OWVT-1, was stored on potato dextrose agar (PDA; Oxoid Ltd., Basingstoke, Hampshire, England) at $4{ }^{\circ} \mathrm{C}$. Fungal inoculum (a mycelial slurry) was prepared by growing the fungus in a liquid medium (Zhang et al., 2006) on an orbital shaker at $150 \mathrm{rpm}$ for 7 days at $25^{\circ} \mathrm{C}$. The fungal colonies were collected and blended following the method of Liu and Chen (2005). The mycelial slurry was collected, and colony forming units (CFUs) per gram of fresh mycelium was determined by plating a series of slurry dilutions on plates with the same nutrition components as the liquid medium. The number of colonies formed on agar after 2 weeks at $25^{\circ} \mathrm{C}$ was recorded (CFUs per gram of fresh mycelium was $1.6 \times 10^{8}$ in experiment 1 and $2.5 \times 10^{8}$ in experiment 2 ).

Soybean cyst nematode race 4 (originally collected from a soybean field in the suburb of Beijing, China) was cultured on soybean cultivar Zhonghuang 13 in autoclaved soil in the greenhouse. The eggs and J2 were prepared from the newly formed cysts (Liu and Chen, 2001).

\subsection{Soil}

Soil ( $52 \%$ sand, $33 \%$ silt, $15 \%$ clay and $1.03 \%$ organic matter at $\mathrm{pH}$ 6.7) was collected from a corn field in Gaomi County, Shandong Province, China. $H$. glycines was not detected in the soil after wet sieving and sucrose centrifugation (Jenkins, 1964), and $H$. rhossiliensis was not observed on resident nematodes or on $\mathrm{H}$. glycines $\mathrm{J} 2$ added to and extracted from the soil. The field soil was passed through a 2-mm-aperture sieve and stored at room temperature $\left(22-25^{\circ} \mathrm{C}\right)$ for 2 months before being used. For the greenhouse experiment, soil moisture was adjusted to $9 \%$ (9 g water/100 $\mathrm{g}$ dry soil) and heated in a microwave (1-kg lot of soil in a plastic bag at $800 \mathrm{~W}$ for $1.5 \mathrm{~min}$ ) to eliminate nematodes and other microfauna but to allow most fungi and bacteria to survive (Chen et al., 1995).

\subsection{Evaluation of the efficacy of $H$. rhossiliensis in soil infested with nematode eggs (experiment 1)}

A fresh mycelial slurry was added to the field soil (1000 mg wet weight of mycelia/100 g of dry soil), and nematode eggs (5000 eggs $/ 100 \mathrm{~cm}^{3}$ soil) were added at the same time. The soil was mixed thoroughly and placed in 12-cm-diameter pots $\left(240 \mathrm{~cm}^{3}\right)$. Soil without fungal inoculation was used as the control. Soybean seeds of Sturdy variety were surface-disinfested with $0.1 \%$ $\mathrm{NaClO}$ for $3 \mathrm{~min}$. Four seeds were sown per pot, and pots were covered with a plastic film to reduce evaporation. Pots were completely randomized and maintained in a growth chamber at 20$25{ }^{\circ} \mathrm{C}$ at a photoperiod of $12 \mathrm{~h}$ of light and $12 \mathrm{~h}$ of dark. After 7 days, the plastic film was removed and the seedlings were thinned to 2 plants/pot. Thereafter, pots were watered daily. There were four replicates for each treatment (plus or minus added mycelia). At 14, 28, 42, 56 and 70 days after planting, four pots from each treatment were randomly selected and destructively sampled (see Section 2.5).

\subsection{Evaluation of the efficacy of $H$. rhossiliensis in soil infested with nematode eggs or $\mathrm{J} 2$ (experiment 2)}

The procedures for fungal inoculation and soybean plantation in experiment 2 were identical to those in experiment 1 , but the eggs and $\mathrm{J} 2 \mathrm{of} \mathrm{H}$. glycines were used as nematode inoculum, respectively. Four treatments included in experiment 2 were: (1) egg-inoculation-nematode eggs (5000 eggs $/ 100 \mathrm{~cm}^{3}$ soil) were added to soil at the same time as the fungus inoculating; (2) J2-inoculation-J2 $\left(5000 \mathrm{~J} 2 / 100 \mathrm{~cm}^{3}\right.$ soil) in $6 \mathrm{ml}$ sterilized water were added to each pot after thinning (7 days after planting); (3) egg-control (eggCK)-soils with eggs and no fungal inoculum and (4) J2-control (J2-CK)-soils with J2 and no fungal inoculum. For all treatments, $H$. glycines $\mathrm{J} 2\left(3000 \mathrm{~J} 2\right.$ in $4.5 \mathrm{mM} \mathrm{KCl} / 100 \mathrm{~cm}^{3}$ soil) were added to each pot 3 days before that pot was destructively sampled. Nematodes were then extracted and examined along with resident nematodes (see Section 2.5). The other procedures were identical to those in experiment 2 .

\subsection{Sampling}

Four replicate pots per treatment were destructively sampled every 2 weeks after seeding. The soil and plants in each pot were gently removed and placed on a plastic sheet. Mature females and cysts were dislodged from the roots, and roots were carefully removed from soil. Rhizosphere soil (defined as the soil attached to roots after gentle shaking by hand) was collected by crumbing the soil attached to roots lightly and dried at room temperature for $1 \mathrm{~h}$. The roots were rinsed with tap water and root and shoot dry mass were determined. The bulk soil of each pot was thoroughly mixed. 
A subsample of $100 \mathrm{~g}$ of soil was used for extraction of eggs and $\mathrm{J} 2$ using the sucrose flotation-centrifugation technique (Jenkins, 1964; Liu and Chen, 2001). All extracted nematodes were observed at $100 \times$ magnification with an inverted microscope. Nematode eggs and $\mathrm{J} 2$ were counted, and the percentage of $\mathrm{J} 2$ parasitized by fungi was recorded. Nematodes with attached fungal conidia or those that were colonized by fungal mycelium were considered to be parasitized.

From each pot, $0.5 \mathrm{~g}$ of rhizosphere soil (in experiment 1) and bulk soil (in experiment 2) were used for DNA extraction with the MoBio UltraClean soil DNA isolation kit (MoBio Laboratories, Solana Beach, CA, USA) according to the manufacturer's protocol with minor revision: that is, beating at $4200 \mathrm{rpm}$ for $90 \mathrm{~s}$ in a mini-bead beater (Biospec Products, Bartlesville, OK, USA) instead of vortexing to break up cells. The DNA was stored at $-20^{\circ} \mathrm{C}$ before use. Soil DNA was diluted 10-fold and subjected to real-time PCR as described in the next section.

\subsection{Real-time PCR quantification of $H$. rhossiliensis in soil}

Hirsutella rhossiliensis DNA in soil was quantified by real-time PCR with specific primers (F419 and R480) and probe (P442) as described previously (Zhang et al., 2006). The TaqMan ${ }^{\mathrm{TM}}$ fluorescent probe was labeled at the $5^{\prime}$ end with the reporter dye FAM (6-carboxy-fluorescein) and at the $3^{\prime}$ end with the quencher dye TAMRA (6-carboxy-tetramenthylrhodamine) (Takara Bio Inc. Otsu, Shiga, Japan). Real-time PCR was performed in $25-\mu 1$ reaction mixtures that contained $1 \times$ buffer; $2.5 \mathrm{mM} \mathrm{MgCl}_{2} ; 100 \mu \mathrm{M}$ each dNTP and $1 \mathrm{U}$ Taq DNA polymerase (Promega, Madison, WI, USA) and $2 \mu \mathrm{l}$ of DNA template. The optimized thermal cycling consisted of a denaturation step of $95^{\circ} \mathrm{C}$ for $10 \mathrm{~min}$ followed by 45 cycles of $95^{\circ} \mathrm{C}$ for $15 \mathrm{~s}$ and $60^{\circ} \mathrm{C}$ for $1 \mathrm{~min}$. Reactions were carried out in an ABI Prism 7700 Sequence Detector (PE Applied Biosystems, Foster, CA, USA). The amount of initial template DNA was estimated by determining the threshold cycle, the cycle number at which statistically significant increases in the reporter fluorescence were detected. Standard curves were constructed based on real-time PCR amplification of five known $H$. rhossiliensis genomic DNA concentrations ranging from $1 \times 10^{3}$ to $1 \times 10^{7}$ femtograms (fg).

\subsection{Statistical analysis}

To determine the biocontrol effectiveness of the fungus, the percent suppression of $H$. glycines and the percent plant growth promotion were calculated at the end of the experiments. Percent suppression was equal to $(1-x) \times 100$, where $x$ was the number of nematode eggs per unit of soil in the fungal inoculation treatment divided by the number of nematode eggs per unit of soil in the con- trol. Percent growth promotion was equal to $(y-1) \times 100$, where $y$ was the plant dry weight in the fungal inoculation treatment divided by the plant dry weight in the control (Lackey et al., 1994). Before being subjected to statistical analysis, nematode population density and fungal DNA yield data were log-transformed and the percentages of $\mathrm{J} 2$ parasitized by the fungus were arcsine-transformed to improve variance homogeneity. Analyses of variance were performed using the GLM procedure of SAS for Windows version 8.0. Differences were considered significant at $P<0.05$.

\section{Results}

\subsection{Effectiveness of fungal inoculation in soil infested with nematode eggs (experiment 1)}

In experiment 1 , fungal treatment did not increase plant shoot or root weight (Table 1 ). Numbers of nematode eggs per $\mathrm{cm}^{3}$ soil did not differ between treatments before day 56 but were less in the fungal treatment than in the control on day 56 and 70 (Table 1).

\subsection{The activity and dynamics of $H$. rhossiliensis in soil infested with} nematode eggs (experiment 1)

At each sampling time, J2 were extracted from the soil and examined for fungal parasitism. The percentage of $\mathrm{J} 2$ parasitized by $H$. rhossiliensis was low for all sampling times, ranging from $0.5 \%$ to $2.3 \%$ (Table 1 ). No J2 were parasitized by the fungus in soils that were not inoculated with the fungus.

The quantity of $H$. rhossiliensis DNA as determined by real-time PCR was highest on day 1 and gradually declined over time in soil with fungal inoculation (Fig. 1). H. rhossiliensis was not detected by real-time PCR in soils that were not inoculated with the fungus.

\subsection{Biocontrol effectiveness of $H$. rhossiliensis on $H$. glycines in soil infested with eggs or hatched 22 (experiment 2)}

In experiment 2 , soil was infested with eggs and $\mathrm{J} 2$ of $\mathrm{H}$. glycines at the same concentration level. Shoot weight did not differ between egg-CK and egg-inoculation treatments until day 59 after planting and were higher in egg-inoculation treatment than in egg-CK treatment on day $59(F=7.66 ; d f=3,12 ; P=0.004$; Table 2). J2-inoculation treatment had significantly higher shoot weight than egg-CK treatment after day $17(F=7.36 ; d f=3,12$; $P=0.0044$; Table 2). The lowest shoot weight among all treatments was observed in the J2-CK treatment. Root weight in egg-CK, egginoculation and J2-inoculation treatments showed no significant difference but were significantly higher than that in J2-CK on day

Table 1

Efficacy of Hirsutella rhossiliensis in soil infested with eggs of Heterodera glycines in experiment 1

\begin{tabular}{|c|c|c|c|c|c|c|c|}
\hline $\begin{array}{l}\text { Days after } \\
\text { planting }\end{array}$ & Treatment $^{\mathrm{a}}$ & $\begin{array}{l}\text { Dry shoot weight } \\
(\mathrm{mg})^{\mathrm{b}}\end{array}$ & $\begin{array}{l}\text { Dry root weight } \\
(\mathrm{mg})^{\mathrm{b}}\end{array}$ & $\begin{array}{l}1000 \text { eggs gram } \\
\text { plant }^{\text {b }}\end{array}$ & $\begin{array}{l}\text { Eggs per } \mathrm{cm}^{3} \\
\text { soil }^{\text {b }}\end{array}$ & $\begin{array}{l}\mathrm{J} 2 \text { per } \mathrm{cm}^{3} \\
\text { soil }^{\mathrm{b}}\end{array}$ & $\begin{array}{l}\text { \% Parasitized by } \\
\text { the fungus }\end{array}$ \\
\hline 14 & $\begin{array}{l}\mathrm{CK} \\
\text { Inoculation }\end{array}$ & $\begin{array}{l}233 \pm 5 a \\
223 \pm 16 a\end{array}$ & $\begin{array}{l}33 \pm 12 a \\
43 \pm 11 a\end{array}$ & $\begin{array}{l}17.7 \pm 8.0 \mathrm{a} \\
15.4 \pm 6.9 \mathrm{a}\end{array}$ & $\begin{array}{l}20.0 \pm 9.0 \mathrm{a} \\
16.6 \pm 7.0 \mathrm{a}\end{array}$ & $\begin{array}{l}4.0 \pm 0.8 \mathrm{a} \\
3.8 \pm 1.3 \mathrm{a}\end{array}$ & $\begin{array}{l}0.0 \pm 0.0 \\
2.3 \pm 1.2\end{array}$ \\
\hline 28 & $\begin{array}{l}\mathrm{CK} \\
\text { Inoculation }\end{array}$ & $\begin{array}{l}216 \pm 16 \mathrm{a} \\
197 \pm 14 \mathrm{a}\end{array}$ & $\begin{array}{l}43 \pm 10 a \\
37 \pm 8 a\end{array}$ & $\begin{array}{l}14.3 \pm 5.0 a \\
14.4 \pm 2.9 a\end{array}$ & $\begin{array}{l}13.7 \pm 7.2 \mathrm{a} \\
13.8 \pm 2.6 \mathrm{a}\end{array}$ & $\begin{array}{l}2.7 \pm 1.9 \mathrm{a} \\
4.7 \pm 0.5 \mathrm{a}\end{array}$ & $\begin{array}{l}0.0 \pm 0.0 \\
2.1 \pm 0.8\end{array}$ \\
\hline 42 & $\begin{array}{l}\text { CK } \\
\text { Inoculation }\end{array}$ & $\begin{array}{l}231 \pm 31 \mathrm{a} \\
216 \pm 44 \mathrm{a}\end{array}$ & $\begin{array}{l}41 \pm 6 a \\
40 \pm 7 a\end{array}$ & $\begin{array}{l}14.0 \pm 3.1 \mathrm{a} \\
13.2 \pm 6.2 \mathrm{a}\end{array}$ & $\begin{array}{l}16.4 \pm 4.6 \mathrm{a} \\
13.1 \pm 4.0 \mathrm{a}\end{array}$ & $\begin{array}{l}4.7 \pm 1.3 \mathrm{a} \\
4.3 \pm 0.9 \mathrm{a}\end{array}$ & $\begin{array}{l}0.0 \pm 0.0 \\
0.5 \pm 0.4\end{array}$ \\
\hline 56 & $\begin{array}{l}\mathrm{CK} \\
\text { Inoculation }\end{array}$ & $\begin{array}{l}250 \pm 27 a \\
214 \pm 13 a\end{array}$ & $\begin{array}{l}44 \pm 5 a \\
48 \pm 11 a\end{array}$ & $\begin{array}{l}13.2 \pm 1.0 \mathrm{a} \\
9.3 \pm 2.8 \mathrm{a}\end{array}$ & $\begin{array}{l}16.4 \pm 0.5 \mathrm{a} \\
10.0 \pm 3.0 \mathrm{~b}\end{array}$ & $\begin{array}{l}7.2 \pm 1.5 \mathrm{a} \\
5.4 \pm 1.2 \mathrm{a}\end{array}$ & $\begin{array}{l}0.0 \pm 0.0 \\
1.3 \pm 0.6\end{array}$ \\
\hline 70 & $\begin{array}{l}\text { CK } \\
\text { Inoculation }\end{array}$ & $\begin{array}{l}229 \pm 33 a \\
220 \pm 59 a\end{array}$ & $\begin{array}{l}56 \pm 16 a \\
42 \pm 13 a\end{array}$ & $\begin{array}{l}8.8 \pm 1.8 \mathrm{a} \\
5.2 \pm 2.4 \mathrm{a}\end{array}$ & $\begin{array}{l}10.8 \pm 3.2 \mathrm{a} \\
5.4 \pm 2.1 \mathrm{~b}\end{array}$ & $\begin{array}{l}4.0 \pm 1.6 \mathrm{a} \\
3.0 \pm 1.7 \mathrm{a}\end{array}$ & $\begin{array}{l}0.0 \pm 0.0 \\
1.1 \pm 0.8\end{array}$ \\
\hline
\end{tabular}

\footnotetext{
a Treatment: without fungal inoculation (CK),with fungal inoculation (Inoculation).

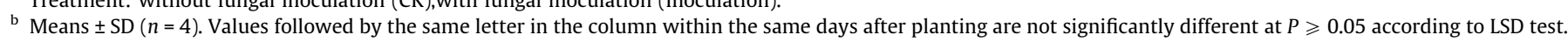
Egg and $\mathrm{J} 2$ densities were transformed to $\log 10(x)$ values before being subjected to statistical analysis.
} 


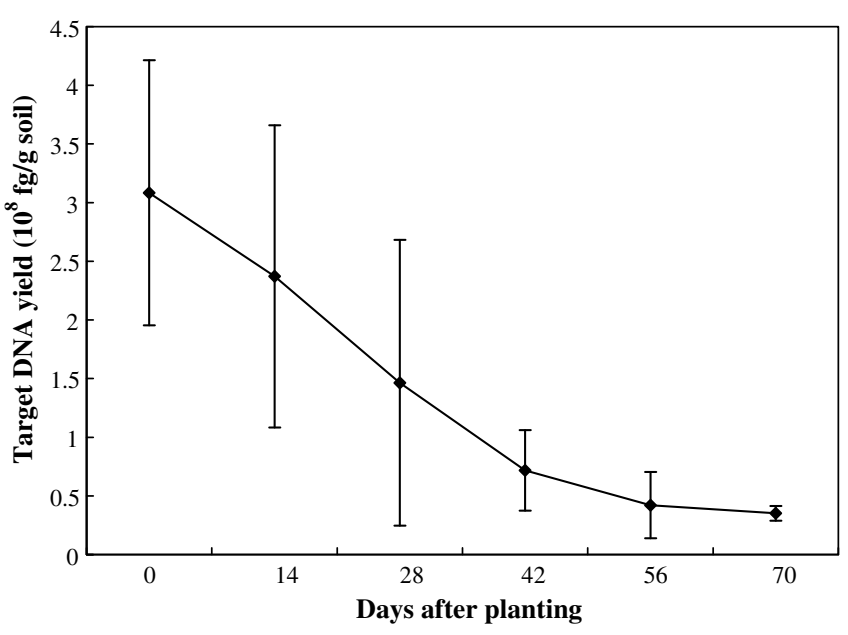

Fig. 1. Quantity of Hirsutella rhossiliensis DNA in the rhizosphere soil of soybean plants in experiment 1 . Values are the means $\pm \operatorname{SD}(n=4)$.

$45(F=9.99 ; d f=3,12 ; P=0.0014)$, and on day $59(F=23.45 ; d f=3$, $12 ; P<0.0001$ ) (Table 2 ). The plant growth promotion was $55 \%$ in J2-infested soil and $2 \%$ in egg-infested soil on day 59 .

Nematode population density, expressed as the number of eggs per gram plant and the number of eggs per $\mathrm{cm}^{3}$ soil, was greatly reduced by fungal inoculation treatment in $\mathrm{J} 2$-infested soil but only marginally in egg-infested soil (Table 2 ). The highest population density of nematodes among all treatments was observed in J2-CK treatment (Table 2). The number of eggs in J2-CK treatment was over 10 times higher than that in egg-CK treatment (Table 2), indicating the greater nematode inoculum potential in soil infested with J2. Suppression of the fungus on nematode in the number of nematode eggs per $\mathrm{cm}^{3}$ soil was $79 \%$ in J2-infested soil, greater than the $34 \%$ in egg-infested soil on day 59 .

\subsection{The activity and growth dynamics of $H$. rhossiliensis in soil infested with eggs or $\mathrm{J} 2$ (experiment 2)}

For bioassaying $H$. rhossiliensis parasitism of nematodes, newly hatched $\mathrm{J} 2$ were added 3 days before destructive sampling of each replicate pot in experiment 2 , and then extracted from soil and examined along with resident nematodes. The percentage of $\mathrm{J} 2$ parasitized by $H$. rhossiliensis declined from $48 \%$ and $42 \%$ on day
17 to $15 \%$ and $12 \%$ on day 59 in egg-inoculation treatment and J2-inoculation treatment, respectively, and showed no statistical difference between two nematode infestation methods (Fig. 2A). No J2 was observed to be parasitized by the fungus in egg-CK and J2-CK treatments. The quantitative data from real-time PCR showed that the amount of $H$. rhossiliensis DNA was highest $\left(3.83 \pm 1.96 \times 10^{8} \mathrm{fg} / \mathrm{g}\right.$ soil $)$ on day 1 , and decreased significantly to $7.34 \pm 2.94 \times 10^{7} \mathrm{fg} / \mathrm{g}$ soil in $\mathrm{J} 2$-inoculation treatment $(F=40.01 ; d f=4,15 ; P<0.0001)$ and $3.24 \pm 1.22 \times 10^{7} \mathrm{fg} / \mathrm{g}$ soil in egg-inoculation treatment $(F=78.51 ; d f=4,15 ; P<0.0001)$ on day 17 (Fig. 2B). The quantity of $H$. rhossiliensis DNA showed no significantly decreasing from day 17 to day 31 in J2-inoculation treatment, and from day 17 to day 45 in egg-inoculation treatment. The lowest DNA yield was observed on day 45 and day 59 in J2-inoculation treatment with 11.1 times lower than day 1 , and on day 59 in egg-inoculation treatment with 19.5 times lower than day 1 (Fig. 2B). The DNA yield was significantly higher in J2-infested soil than in egg-infested soil on day $17(F=8.94 ; d f=1,6 ; P=0.0243)$ and day $31(F=19.09 ; d f=1,6 ; P=0.0047)$ (Fig. 2B). H. rhossiliensis was not detected by real-time PCR in egg-CK and J2-CK treatments.

\section{Discussion}

Maintaining an introduced fungus in the soil is the key to maximizing its effect on the nematode population. In our study, results based on real-time PCR showed that the quantity of $H$. rhossiliensis DNA declined over time in eggs-infested or J2-infested soil. In experiment 2 , the quantity of $H$. rhossiliensis DNA decreased by 5.2 and 11.8 times from day 1 to day 17 , and then by 2.1 and 1.7 times from day 17 to day 59 in J2-infested soil and egg-infested soil, respectively, which indicated that the establishment and survival of the fungus were greatly affected by some biotic antagonism or abiotic environmental factors after the fungus was introduced to soil, especially in the earlier period.

The results in experiment 2 showed that nematode population density in J2-CK treatment was significantly higher than that in egg-CK treatment 45 days after planting in experiment 2, and that suppression of soybean cyst nematodes by $H$. rhossiliensis was significantly less in egg-infested soil than in J2-infested soil. These data shared some features with Lackey et al. (1994), who reported that the fungus was more effective in controlling sugar beet cyst nematodes in soil infested with $\mathrm{J} 2$ than in soil infested with egg masses or cysts. Lackey et al. (1994) inferred that the J2 in eggs re-

Table 2

Efficacy of Hirsutella rhossiliensis in soil infested with eggs or juveniles of Heterodera glycines in experiment 2

\begin{tabular}{|c|c|c|c|c|c|}
\hline Days after planting & Treatment $^{\mathrm{a}}$ & Dry shoot weight $(\mathrm{mg})^{\mathrm{b}}$ & Dry root weight $(\mathrm{mg})^{\mathrm{b}}$ & 1000 eggs per gram plant ${ }^{b}$ & Eggs per $\mathrm{cm}^{3}$ soil $^{\mathrm{b}}$ \\
\hline \multirow[t]{4}{*}{17} & Egg-CK & $234 \pm 13 a$ & - & - & - \\
\hline & Egg-inoculation & $236 \pm 22 a$ & - & - & - \\
\hline & $\mathrm{J} 2-\mathrm{CK}$ & $223 \pm 26 a$ & - & - & - \\
\hline & $\mathrm{J} 2$-inoculation & $227 \pm 39 a$ & - & - & - \\
\hline \multirow[t]{4}{*}{31} & Egg-CK & $251 \pm 27 a$ & - & - & - \\
\hline & Egg-inoculation & $276 \pm 11 \mathrm{a}$ & - & - & - \\
\hline & $\mathrm{J} 2-\mathrm{CK}$ & $189 \pm 23 c$ & - & - & - \\
\hline & J2-inoculation & $231 \pm 40 \mathrm{~b}$ & - & - & - \\
\hline \multirow[t]{4}{*}{45} & Egg-CK & $274 \pm 20 a$ & $70 \pm 18 a$ & $22 \pm 8 c$ & $33 \pm 10 c$ \\
\hline & Egg-inoculation & $273 \pm 45 a$ & $64 \pm 8 a$ & $15 \pm 5 c$ & $22 \pm 4 d$ \\
\hline & $\mathrm{J} 2-\mathrm{CK}$ & $165 \pm 29 b$ & $40 \pm 5 b$ & $590 \pm 82 a$ & $512 \pm 129 a$ \\
\hline & $\mathrm{J} 2$-inoculation & $280 \pm 17 \mathrm{a}$ & $80 \pm 8 a$ & $40 \pm 8 b$ & $60 \pm 12 b$ \\
\hline \multirow[t]{4}{*}{59} & Egg-CK & $286 \pm 84 b$ & $87 \pm 7 a$ & $22 \pm 8 c$ & $37 \pm 16 c$ \\
\hline & Egg-inoculation & $399 \pm 67 a$ & $82 \pm 8 a$ & $11 \pm 4 d$ & $25 \pm 10 c$ \\
\hline & $\mathrm{J} 2-\mathrm{CK}$ & $181 \pm 52 c$ & $47 \pm 6 b$ & $649 \pm 297 a$ & $588 \pm 12 a$ \\
\hline & $\mathrm{J} 2$-inoculation & $272 \pm 48 b$ & $81 \pm 8 a$ & $88 \pm 31 b$ & $126 \pm 31 b$ \\
\hline
\end{tabular}

a Treatment: eggs-infested and without/with fungal inoculation (eggs-CK/eggs-inoculation); J2-infested and without/with fungal inoculation (J2-CK/J2-inoculation).

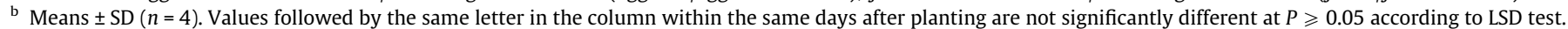
Egg and $\mathrm{J} 2$ densities were transformed to $\log 10(x)$ values before being subjected to statistical analysis. 

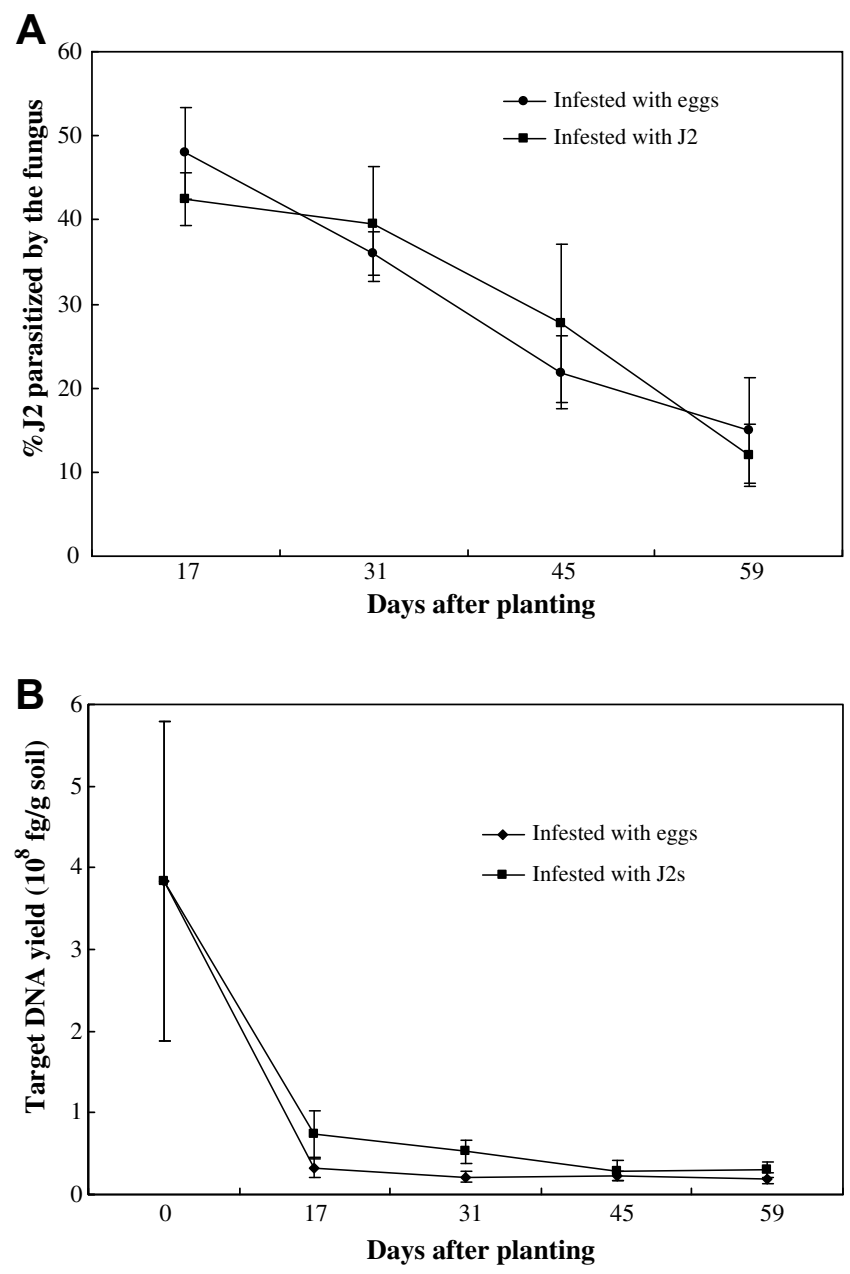

Fig. 2. The percentage of Heterodera glycines juveniles (J2) parasitized by Hirsutella rhossiliensis and quantity of $H$. rhossiliensis DNA in soil planted with soybean. (A) The percentage of $H$. glycines $\mathrm{J} 2$ parasitized by $H$. rhossiliensis. (B) The quantity of $H$. rhossiliensis DNA (fg/g soil) based on real-time PCR. Values are the means \pm SD $(n=4)$.

mained in eggs until roots were near, traveled short distances through the soil, and thus reduced their chance of encountering the conidia of $H$. rhossiliensis. The small number of $\mathrm{J} 2$ and limited movement through the soil would minimize not only the chance of invading soybean roots but also the chance of encountering the conidia of $H$. rhossiliensis, which resulted in a lower nematode inoculum potential and poor suppression efficiency of the fungus on the nematode.

The small number of $\mathrm{J} 2$ and their limited movement might also account for the persistently low percentage of $\mathrm{J} 2$ parasitized by $H$. rhossiliensis (0.5-2.3\%) in experiment 1, where fungal parasitism was determined by extracting nematodes directly from soil without addition of bait J2. The quantity of $H$. rhossiliensis DNA, which ranged from $3.10 \pm 1.60 \times 10^{8}$ to $3.52 \pm 0.63 \times 10^{7} \mathrm{fg} / \mathrm{g}$ soil in experiment 1 , was comparable to $3.83 \pm 1.96 \times 10^{8}$ to $1.96 \pm 6.39 \times 10^{7} \mathrm{fg} / \mathrm{g}$ soil in experiment 2 , indicating that the failure to parasitize in experiment $1 \mathrm{did}$ not result from the absence of the fungus. Fungal parasitism of nematodes in experiment 2, estimated by adding fresh $\mathrm{J} 2$ to the soil 3 days before sampling and then extracting and examining the $\mathrm{J} 2$, was higher (12-48\%) than that in experiment $1(0.5-2.3 \%)$. One interpretation is that the determination of fungal parasitism based on baiting overestimated the chance of encountering the conidia due to the addition of fresh J2 (Lackey et al., 1994). Much of the uncertainty associated with the bioassay is eliminated by real-time PCR because the latter does not depend on nematode movement through soil and detects all fungal propagules directly (Zhang et al., 2006).

In experiment 2, real-time PCR assay showed that the amount of $H$. rhossiliensis DNA was statistically higher in J2-inoculation treatment than in egg-inoculation treatment in the earlier period (prior to day 31) after being introduced to soil. The result was partially consistent with the investigation over a period of 2 year in an agricultural soil by Persmark et al. (1996) showing that there is a positive relationship between the number of nematodes and the endoparasitic fungi in agricultural soil. The higher DNA yield of $H$. rhossiliensis in J2-infested soil during this period indicated a larger biomass than in egg-infested soil. Under natural conditions, $H$. rhossiliensis is an endoparasite of nematodes and depends on nematodes for nutrition (Jaffee and Muldoon, 1989; Jaffee et al., 1993). Previous laboratory studies have confirmed that the probability of parasitism of nematodes by $H$. rhossiliensis increases with increased host density (Jaffee et al., 1993; Jaffee and Muldoon, 1995). The J2 of nematode is the entity which $H$. rhossiliensis parasitizes. The presence of $\mathrm{J} 2$ at high concentrations in the earlier period provided a plentiful nutrient source for the fungus, and consequently resulted in higher biomass in J2-infested soil. The quantity of $H$. rhossiliensis DNA in J2-infested soil decreased over time and showed no significant difference with egg-infested soil 45 days after planting, which could be attributed to the low nematode propagation as a result of effective nematode suppression by the fungus. It seems possible that the numbers of $\mathrm{J} 2$ present during and soon after fungal inoculation affected the establishment of the fungus in soil.

To achieve successful and reproducible biological control, we must understand the ecological interactions affecting the control agent and the target (Whipps, 1997, 2001). Real-time PCR provides an effective way to quantify biocontrol agents after they are added to soil. In our study, the results based on real-time PCR assay showed that the DNA yield of $H$. rhossiliensis decreased over time regardless of eggs or J2 as inoculum, and that the DNA yield of $H$. rhossiliensis was statistically higher in J2-infested soil than in egg-infested soil in the earlier period. Thus, the fungus showed greater efficiency in suppressing nematodes in J2-infested soil than in egg-infested soil. We also note that nematode densities were initially higher in J2-infested soil, suggesting that the nematode density could affect the ability of $H$. rhossiliensis to establish in soil. Further studies are necessary to determine how various biotic and abiotic factors affect $H$. rhossiliensis DNA quantity in soil. The relationship between DNA quantity and nematode control by $H$. rhossiliensis also requires additional research. With the resulting knowledge, researchers should be better able to predict conditions that favor biocontrol by the fungus.

\section{Acknowledgments}

This work was jointly supported by National Outstanding Youth Foundation (30625001), National 863 Plan of China (2006AA10A211) and Beijing Municipal Science and Technology Commission (D0706005040331 and D0705002040191). The authors also thank Prof. Bruce A. Jaffee (the University of California at Davis) for serving as pre-submission reviewers and for his valuable comments and suggestions.

\section{References}

Amin, A.W., 2000. Efficacy of Arthrobotrys oligospora, Hirsutella rhossiliensis, Paecilomyces lilacinus and Pasteuria penetrans as potential biocontrol agents against Meloidogyne incognita on tomato. Pakistan Journal of Nematology 18, 29-33.

Chen, S.Y., Dickson, D.W., Mitchell, D.J., 1995. Effects of soil treatments on the survival of soil microorganisms. Journal of Nematology 27, 661-663. 
Chen, S.Y., Liu, X.Z., 2005. Control of the soybean cyst nematode by the fung Hirsutella rhossiliensis and Hirsutella minnesotensis in greenhouse studies. Biological Control 32, 208-219.

Ciancio, A., Logrieco, A., Lamberti, F., 1986. Parasitism of Xiphinema diversicaudatum by the fungus Hirsutella rhossiliensis. Nematologia Mediterranea 14, 187-192.

Cook, R.J., Baker, K.F., 1983. The Nature and Practice of Biological Control of Plant Pathogens. America Phytopathological Society, St Paul, MN.

Hay, F.S., 1995. Endoparasites infecting nematodes in New Zealand. New Zealand Journal of Botany 33, 401-407.

Jaffee, B.A., Muldoon, A.E., 1995. Numerical responses of the nematophagous fungi Hirsutella rhossiliensis, Monacrosporium cionopagum, and M. ellipsosporum. Mycologica 87, 643-650.

Jaffee, B.A., 1999. Enchytraeids and nematophagous fungi in tomato fields and vineyards. Phytopathology 89, 398-406.

Jaffee, B.A., Muldoon, A.E., 1989. Suppression of cyst nematode by natura infestation of a nematophagous fungus. Journal of Nematology 21, 505-510.

Jaffee, B.A., Muldoon, A.E., Anderson, C.E., Westerdahl, B.B., 1991. Detection of the nematophagous fungus Hirsutella rhossiliensis in California sugarbeet fields. Biological Control 1, 63-67.

Jaffee, B.A., Muldoon, A.E., Westerdahl, B.B., 1996. Failure of a mycelial formulation of the nematophagous fungus Hirsutella rhossiliensis to suppress the nematode Heterodera schachtii. Biological Control 6, 340-346.

Jaffee, B.A., Tedford, E.C., Muldoon, A.E., 1993. Tests for density-dependent parasitism of nematodes by nematode-trapping and endoparasitic fungi. Biological Control 3, 329-336.

Jaffee, B.A., Zasoski, R.J., 2001. Soil pH and the activity of a pelletized nematophagous fungus. Phytopathology 91, 324-330.

Jenkins, W.R., 1964. A rapid centrifugal-flotation technique for separating nematodes from soil. Plant Disease Reporter 48, 692

Lackey, B.A., Jaffee, B.A., Muldoon, A.E., 1992. Sporulation of the nematophagous fungus Hirsutella rhossiliensis from hyphae produced in vitro and added to soil. Phytopathology 82, 415-420.

Lackey, B.A. Jaffee, B.A. Muldoon, A.E. 1994. Effect of nematode inoculum on suppression of root-knot and cyst nematodes by the nematophagous fungus Hirsutella rhossiliensis. Phytopathology 84, 415-420.

Liu, X.Z., Chen, S.Y., 2000. Parasitism of Heterodera glycines by Hirsutella spp. in Minnesota soybean fields. Biological Control 19, 161-166.

Liu, X.Z., Chen, S.Y., 2001. Screening isolates of Hirsutella species for biocontrol of Heterodera glycines. Biocontrol Science and Technology 11, 151-160.
Liu, S.F., Chen, S.Y., 2005. Efficacy of the fungi Hirsutella minnesotensis and Hirsutella rhossiliensis from liquid culture for control of the soybean cyst nematode. Nematology 7, 149-157.

McInnis, T.M., Jaffee, B.A., 1989. An assay for Hirsutella rhossiliensis spores and the importance of phialides for nematode inoculation. Journal of Nematology 21, 229-235.

Pereira, R.M., Stimac, J.L., Alves, S.B., 1993. Soil antagonism affecting the dose response of workers of the red imported fire ant, Solenopsis invicta, to Beauveria bassiana conidia. Journal of Invertebrate Pathology 61, 156-161.

Rosskopf, E.N., Chellemi, D.O., Kokalis-Burelle, N., Church, G.T., 2005. Alternatives to Methyl Bromide: A Florida Perspective. APSnet Feature. Available from: <http:// www.apsnet.org/online/feature/methylbromide/default.asp> .

Persmark, L., Banck, A., Jansson, Hans-Borje., 1996. Population dynamics of nematophagous fungi and nematodes in an arable soil: vertical and seasonal fluctuations. Soil Biology and Biochemistry 28, 1005-1014

Stirling, G.R., 1991. Biological Control of Plant Parasitic Nematodes. CAB International, Wallingford, UK.

Tedford, E.C., Jaffee, B.A., Muldoon, A.E., 1992. Effects of soil moisture and texture on transmission of the nematophagous fungus Hirsutella rhossiliensis to cyst and root-knot nematedes. Phytopathology 82, 1002-1007.

Tedford, E.C., Jaffee, B.A., Muldoon, A.E., Anderson, C.E., Westerdahl, B.B., 1993. Parasitism of Heterodera schachtii and Meloidogyne javanica by Hirsutella rhossiliensis in microplots over two growing seasons. Journal of Nematology 25, 427-433.

Velvis, H., Kamp, P., 1995. Infection of second stage juveniles of potato cyst nematodes by the nematophagous fungus Hirsutella rhossiliensis in Dutch potato field. Nematologica 41, 617-627.

Velvis, H., Kamp, P., 1996. Suppression of potato cyst nematode root penetration by the endoparasitic nematophagous fungus Hirsutella rhossiliensis. European Journal of Plant Pathology 102, 115-122.

Whipps, J.M., 1997. Developments in the biological control of soil-borne plant pathogens. Advance in Botanical Research 26, 1-134.

Whipps, J.M., 2001. Microbial interactions and biocontrol in the rhizosphere. Journal of Experimental Botany 52, 487-511.

Wrather, J.A., Koenning, S.R., 2006. Estimates of disease effects on soybean yields in the United States 2003-2005. Journal of Nematology 38, 173-180.

Zhang, L.M., Liu, X.Z., Zhu, S.F., Chen, S.Y., 2006. Detection of the nematophagous fungus Hirsutella rhossiliensis in soil by real-time PCR and parasitism bioassay. Biological Control 36, 316-323. 